\title{
Ksantofiller ve Sağlıkla İlişkileri
}

\section{Xanthophylls and Their Relationship with Health}

\author{
Tuba Yalçın ${ }^{1}$ Zehra Büyüktuncer ${ }^{2}$
}

Geliş tarihi/Received: 07.03.2019 • Kabul tarihi/Accepted: 01.08.2019

\section{ÖZET}

Ksantofiller; bitkiler, diğer fotosentetik organizmalar (algler, funguslar) ve fotosentez yapmayan bazı maya ve küflerce sentezlenen tetraterpenik organik pigmentlerdir. Bu bileşikler fotosentetik organizmalarda bulunmakta ve sarıdan kırmızıya çoğu meyve ve sebzeye rengini vermektedir. Diyetle alımları özellikle meyve ve sebzelerden sağlanmaktadır. Vücuttaki emilim ve biyoyararlılıkları çeşitli faktörlerden etkilenmektedir. Diyet ksantofillerinin sahip oldukları biyolojik aktiviteler ile göz, kalp-damar, kemik, beyin sağlığı ile diyabet, obezite ve kanserler gibi kronik hastalıkların oluşumu ve seyrinde yararlı etkiler oluşturabildiği gösterilmiştir. Özellikle antioksidan aktiviteleri ve kronik hastalıklar üzerindeki potansiyel önleyici ve/veya teröpatik etkileri nedeniyle günümüzde ilgi odağı durumundadırlar. Bu derleme makalede; ksantofillerin biyoyararlılığı ve sağlık üzerine etkileri özetlenmiştir.

Anahtar Kelimeler: Ksantofiller, biyolojik aktivite, sağlık

\begin{abstract}
Xanthophylls are tetraterpenic organic pigments which are synthesized in plants and other photosynthetic organisms (algas and fungus) as well as in some non-photosynthetic molds and yeasts. These compounds exist in photosynthetic organisms and assign the colors of most fruits and vegetables from yellow to red. Dietary intakes are particularly from fruits and vegetables. Their absorption and bioavailability in the body are affected by various factors. Dietary xanthophylls have been shown to have beneficial effects on the formation and course of chronic diseases such as eye, cardiovascular, bone, brain health and diabetes, obesity and cancers through their biological activities. Especially, due to their antioxidant activities and potential preventive and/or therapeutical properties on chronical diseases, they are now the focus of attention. In this review article, the bioavailability of xanthophylls and their effects on health were summarized.
\end{abstract}

Keywords: Xanthophylls, biological activity, health

1. Hacettepe Üniversitesi, Sağllk Bilimleri Fakültesi, Beslenme ve Diyet Bölümü, Ankara, Türkiye

(1) https://orcid.org/0000-0002-4820-8180
2. İletişim/Correspondence: Hacettepe Üniversitesi, Sağllk Bilimleri Fakültesi, Beslenme ve Diyetetik Bölümü, Ankara, Türkiye E-posta: zbtuncer@hacettepe.edu.tr • 『 https://orcid.org/0000-0002-2039-8568 


\section{GİRIŞ}

Karotenoidler, meyvelerde ve sebzelerde yaygin olarak bulunan pigmentlerdir. Ksantofiller ve karotenler olarak iki sınıfa ayrılmaktadır. Karotenler sadece karbon ve hidrojenden oluşurken, ksantofiller yapılarında hidroksil grubu içermektedir. Bu nedenle karotenlere göre daha hidrofilik yapıdadır (1). İşleme, öğün bileşimi, sindirim enzim aktivitesi de dahil olmak üzere pekçok faktör ksantofillerin biyoyararlılığına etki etmektedir (2).

Sindirim kanalında ksantofiller, misellere katılmakta ve bağırsak hücrelerinden basit veya kolaylaştırılmış difüzyonla emilmektedir. Kanda sadece lipoproteinler aracılığıyla taşınmakta ve membran bağımlı lipit taşıyıcıları ile dokulara alınmaktadır. Kandaki ve dokulardaki ksantofil düzeyleri, diyetle alımın sonucudur. Yetersiz ksantofil alımının sağlıkla ilgili eksikliklere neden olmayacağı ancak sağlıklı bir diyetle yeterli ksantofil alımının optimal sağlığı geliştirici ve/veya kronik hastalıkları önleyici etkilerinin olduğu belirtilmektedir (1). Bu derleme makalede; ksantofillerin sağlık üzerine etkileri güncel literatür ışığında incelenmiştir.

\section{Ksantofillerin Sağlık Üzerine Etkileri}

Ksantofiller esansiyel olmayan besin ögeleri olarak değerlendirilmelerine rağmen bileşimlerindeki karbon-karbon çift bağlarının konjuge yapısından dolayı antioksidan özellik göstermektedir. Serbest radikalleri süpürerek, radikallerin yol açabileceği zincir reaksiyonlara karşı koruma sağlayarak ve/veya oluşmuş olan zincir reaksiyonlarını sonlandırarak etki göstermektedir. Ksantofillerin sağlık üzerindeki etkileri genellikle antioksidan özellikleri ile ilişkilendirilmektedir (3). Besinlerde en çok bulunan ksantofil türleri ve özellikleri Tablo 1’de özetlenmiştir.

Tablo 1. Besinlerde en çok bulunan ksantofil türleri ve özellikleri

\begin{tabular}{|c|c|c|c|c|}
\hline Ksantofiller & Bulunduğu besin & Rengi & Olası etkisi & $\begin{array}{l}\text { Günlük doz alım } \\
\text { önerisi }\end{array}$ \\
\hline Lutein & $\begin{array}{l}\text { Yeşil yapraklı sebzeler, lahana } \\
\text { dış yaprakları, balkabağı, } \\
\text { yumurta sarısı (4) }\end{array}$ & $\begin{array}{l}\text { Kırmizl, } \\
\text { turuncu (3) }\end{array}$ & $\begin{array}{l}\text { Antioksidan, tümör gelişimini } \\
\text { engelleyici etki (akciğer, meme } \\
\text { kanseri) (3) }\end{array}$ & $\begin{array}{l}13.4 \text { mg/kişi/gün } \\
\text { [FDA- GRAS] (5) }\end{array}$ \\
\hline Zeaksantin & $\begin{array}{l}\text { Turuncu biber, sarı mısır, yeşil } \\
\text { yapraklı sebzeler, yumurta } \\
\text { sarısı, kivi, kırmızıbiber (6) }\end{array}$ & $\begin{array}{l}\text { Turuncu, } \\
\text { kirmizl (6) }\end{array}$ & $\begin{array}{l}\text { Antioksidan, retinayı koruyucu, } \\
\text { kardiyovasküler hastalıkları önleyici, } \\
\text { tümör gelişimini engelleyici etki } \\
\text { (akciğer, meme kanseri) }(4,6)\end{array}$ & $\begin{array}{l}2.4 \text { mg/kişi/gün } \\
\text { [FDA- GRAS] (5) }\end{array}$ \\
\hline Kantaksantin & $\begin{array}{l}\text { Bakteriler, çeşitli kabuklular, } \\
\text { sazan balığı, bazı balıklar (6) }\end{array}$ & $\begin{array}{l}\text { Koyu turuncu- } \\
\text { kırmızı (3) }\end{array}$ & $\begin{array}{l}\text { Antioksidan, antibiyotik, tümör } \\
\text { gelişimini engelleyici etki }(3,6)\end{array}$ & $\begin{array}{l}0.03 \mathrm{mg} / \mathrm{kg} / \mathrm{gün} \\
\text { [EFSA- ADI] (7) }\end{array}$ \\
\hline Astaksantin & $\begin{array}{l}\text { Somon, istakoz, karides, krill, } \\
\text { kırmızı okyanus bitkileri, maya } \\
\text { (6) }\end{array}$ & Kırmızı (8) & $\begin{array}{l}\text { Antioksidan, antiinflamatuar, kan } \\
\text { basıncını düzenleyici, kan glukoz } \\
\text { düzeyini düşürücü etki }(6,8)\end{array}$ & $\begin{array}{l}\text { 2-6 mg/gün } \\
\text { [NOAEL] (9) }\end{array}$ \\
\hline B-kriptoksantin & $\begin{array}{l}\text { Tatlı kırmızıbiber, hurma, } \\
\text { mandalina, portakal (6) }\end{array}$ & Sarl (6) & $\begin{array}{l}\text { Antiinflamatuar etki, osteoporoz } \\
\text { riskini azaltıcı, karaciğer } \\
\text { hastalıklarını önleyici, kansere karşı } \\
\text { koruyucu etki (6) }\end{array}$ & $\begin{array}{l}\text { ADI değeri yok. } \\
\text { Mutajenik ya da } \\
\text { toksik etki yok (10) }\end{array}$ \\
\hline Fukoksantin & Kahverengi alg (3) & $\begin{array}{l}\text { Kahverengi, } \\
\text { turuncu (6) }\end{array}$ & $\begin{array}{l}\text { Antioksidan, antiinflamatuar, tümör } \\
\text { gelişimini engelleyici, termogenezi } \\
\text { arttırıcı etki }(3,11)\end{array}$ & $\begin{array}{l}\text { Mutajenik ya da } \\
\text { toksik etki yok (6) }\end{array}$ \\
\hline
\end{tabular}




\section{Göz sağlığı üzerine etkisi}

Lutein ve zeaksantin özellikle göz sağlığı ile ilişkilendirilen ksantofillerdir. $\mathrm{Bu}$ ksantofillerin fotoreseptörlerde oluşan serbest radikalleri yakalayarak ve makulayı ışı nedenli hasardan koruyarak etki gösterdiği düşünülmektedir. Bu nedenle maküler dejenerasyonun ilerlemesini önlemede, lutein ve zeaksantin gibi ksantofiller anahtar rol oynayabilmektedir (12). Diyetle lutein ve zeaksantin alımının artırılmasının, yaşa bağlı maküler dejenerasyon (Age-Related Macular Degeneration, AMD) gelişimine karşı koruyucu olduğu bildirilmektedir (13). Yapllan bir meta-analizin sonuçları lutein ve zeaksantin suplementasyonunun, AMD tanısı almış bireylerde görme fonksiyonunu iyileştirdiğini göstermiştir (14). Otsuka et al. (15) farelerde yaptıkları çalışmada diyetle astaksantin alımının ışığa bağlı retinal hücre ölümüne karşı koruyucu olduğu ve AMD’nin ilerlemesini önlediğini rapor etmiştir. Yapılan bir başka hayvan çalışmasında ise astaksantinin kan beyin bariyerinden geçtiği ve memelilerde retinada depo edildiği gösterilmiş, farelerde retinal reseptörleri UV ışınlarından koruduğu saptanmıştır (16).

\section{Kanser üzerine etkisi}

Ksantofillerin, hücreler arası boşlukta iletişimi geliştirme, antioksidan aktivite gösterme, bağışıklık sistemini güçlendirme, anjiogenezi engelleme gibi özellikleri ile kanser oluşumunu önlemede önemli rol oynadıkları düşünülmektedir (17). Yasui et al. (18), farelerde yaptıkları çalışmada astaksantinin inflamasyonla ilişkili karsinogenezi önlemede etkili olduğunu belirtmiştir. Farelerde yapılan bir başka çalışmanın sonuçları astaksantin ve kantaksantinin mesane ve kolorektal kanser gelişimini, hücre proliferasyonunu baskılayarak önlediği; özellikle mesane kanserinin önlenmesinde astaksantinin, kantaksantine göre hücre proliferasyonunu baskılayıcı yeteneğinin daha fazla olduğunu göstermiştir (19). Yapılan in vitro çalışmalarda ise fukoksantinin karaciğer, kolon, mesane gibi kanser türlerinde kanser hücrelerini inhibe edici etkisi gösterilmiştir (20,21). Uzun dönem izlemli epidemiyolojik çalışmalarda diyetle ksantofil alımı fazla olan bireylerde bazı kanser türlerinin gelişim risklerinin daha düşük olduğu gösterilmiştir $(6,22)$. Dokuz yıl süren takipli bir çalışmada, serum lutein düzeyi düşük olan bireylerde meme kanseri görülme oranının, yüksek olan bireylere kıyasla iki kat fazla olduğu gözlenmiştir (22). Amerikalı 120.000 kadın ve erkek ile 10 yll süresince yürütülen bir başka çalışmada ise lutein ve zeaksantinden zengin diyetle beslenen bireylerde akciğer kanseri görülme oranının daha düşük olduğu rapor edilmiştir (23). Yapılan bir vaka-kontrol çalışmasında ise lutein ve zeaksantinin serum düzeyleri ile meme kanseri arasında anlamlı bir ilişki gözlenmediği rapor edilmiştir (24).

\section{Kardiyovasküler sistem üzerine etkisi}

Oksidatif stres ve inflamasyon, kardiyovasküler hastalıkların gelişiminde anahtar rol oynamaktadır. Ksantofillerin ise antioksidan veya antiinflamatuvar etkileriyle bu riski azaltabilecekleri düşünülmektedir (1). Yapılan bir sistematik derlemede, serum lutein konsantrasyonun veya diyetle lutein alımının yüksek olması daha düşük koroner arter hastalığı (KAH) ve inme riski ile ilişkilendirilmiştir (25). İnsan plazmasındaki başlıca karotenoidlerin değerlendirildiği bir çalışmada koroner arter hastalarında sadece lutein ve zeaksantinin, KAH'nın inflamatuvar belirteçlerinden olan interlökin-6 (IL6) ile ters ilişkili olduğu belirlenmiştir (26). Bir başka çalışmada ise, ateroskleroz başlangıcı olan bireylere 3 ay süresince $20 \mathrm{mg} / \mathrm{gün}$ lutein verildiğinde serum IL-6, trigliserit (TG) ve LDL kolesterol düzeylerinde anlamlı düşüş gözlendiği bildirilmiştir (27).

\section{Diyabet üzerine etkisi}

Diyabetik ratlarda yapılan bir çalışmada astaksantinin pankreas $\beta$-hücre fonksiyonunu artırdığı ve kan glukoz düzeyinde anlamlı düşüş sağladığı gösterilmiştir (28). Ni et al. (29) $\beta$-kriptoksantinin insülin direncini azalttığını rapor etmiştir. Jung et al. (30) ise fukoksantinin insülin sinyalizasyonunu iyileştirerek anti-diyabetik etki gösterdiğini belirtmiş; 
bununla birlikte diyabetik hastalarda ileri glikasyon son ürünleri (AGE) oluşumunu inhibe ederek hiperglisemi ile ilişkili komplikasyonları azaltmada etkin olduğunu rapor etmiştir.

\section{Obezite üzerine etkisi}

Diyet ksantofillerinin vücut ağırlığı üzerine olan etkilerindeki temel mekanizmanın termogenezdeki rolleri ile ilişkili olduğu düşünülmektedir. Fukoksantin termogenez olarak bilinen süreçte yağ metabolizması ile ilişkili enzimlere etki ederek yağ dokudan elde edilen 1 sı enerjisi miktarını artırmaktadır (6). Obez fareler ile yapılan bir çalışmada fareler üç gruba ayrılmış; birinci gruba orta zincirli yağ asidi (MCT) (\%0.9), ikinci gruba fukoksantin (\%0.1), üçüncü gruba ise MCT (\%0.9)+fukoksantin (\%0.1) verilmiştir. Fukoksantin ile beslenen farelerdeki abdominal yağ miktarının MCT ile beslenen farelere kıyasla anlamlı şekilde düşük olduğu görülmüştür. $\mathrm{Bu}$ durum, fukoksantinin beyaz adipoz dokuda metabolik termogenezde anahtar molekül olan eşlenmemiş protein 1'in (Uncoupling protein 1, UCP-1) ekspresyonunu artırması ile açıklanmıştır. Bununla birlikte, obezite önleyici etkisinin sadece fukoksantin verilen grup ile kıyaslandığında MCT ve fukoksantinin birlikte verildiği grupta daha yüksek olduğu gösterilmiştir. Bu durumda MCT’nin fukoksantinin emilim oranını artırması ile açıklanmıştır (11). Tsuchida et al. (31) yaptığı plasebo kontrollü çift kör çalışmanın sonucunda ise $\beta$-kriptoksantinin viseral yağ düzeyini, vücut ağırlığını ve bel çevresi ölçümünü azalttığını rapor etmiştir.

\section{Osteoporoz üzerine etkisi}

Ksantofil çeşitleri arasında $\beta$-kriptoksantinin osteoblastik kemik oluşumunu uyarması ve osteoklastik kemik rezorpsiyonunu inhibe etmesi nedeniyle kemik kütlesi üzerinde benzersiz bir anabolik etkisinin olduğu; hem diyetle alımı hem de serumdaki düzeyinin farklıkemikveeklem hastalıkları (osteoartirit, osteoporoz, romatoid artirit vb.) ile ters ilişkili bulunduğu gösterilmiştir (32). Sağlıklı 20 birey ile yürütülen bir çalışmada katılımcılar iki gruba ayrılmış; bir gruba $\beta$-kriptoksantin içeriği 802 mcg/100 $\mathrm{mL}$ olan meyve suyu, diğer gruba ise $\beta$-kriptoksantin ile zenginleştirilmiş (1500 mcg/100 mL) meyve suyu verilmiş ve 56 gün boyunca her gün bu içecekleri tüketmeleri istenmiştir. Çalışmanın sonucunda $\beta$-kriptoksantin alımı ile dolaşımda kemik oluşumunda görevli biyogöstergelerin (osteokalsin vb.) arttığı; kemik ylkımından sorumlu biyogöstergelerin ise azaldığı ve bu etkinin alınan $\beta$-kriptoksantin miktarı ile doğru orantılı olduğu rapor edilmiştir (33). Das et al. (34) ise fukoksantin ile yaptıkları çalışmada, $\beta$-kriptoksantinin kemik sağlığı üzerindeki etkisine benzer şekilde, fukoksantinin osteoklast hücrelerin gelişimini baskılarken, osteoblast hücre canlılığını koruduğunu göstermiştir.

\section{Beyin sağlığı ve bilişsel fonksiyon üzerine etkisi}

Bilişsel fonksiyonlardaki bozulma, bireyin hatırlamada, yeni bilgiler öğrenmede, konsantrasyon sağlamada veya günlük yaşamı etkileyen kararlar almasında zorlanma ile sonuçlanmaktadır (35). Parkinson hastalığı, Huntington hastalığı ve demansın en yaygın şekli olan Alzheimer hastalığı, bilişsel bozukluğu olan kronik ve engelleyici hafıza kaybı ile karakterize dejeneratif beyin hastalıklarıdır (36). Yapılan araştırmalar, oksidatif stresin dejeneratif beyin hastalıklarının gelişiminde oldukça önemli olduğunu göstermiştir (37,38). Renzi et al. (39), lutein ve zeaksantinin antioksidan ve anti-inflamatuar özellikleriyle beyin hücrelerini korumada etkin olduğunu rapor etmiştir. Diyetle alınan astaksantinin de güçlü antioksidan özelliği nedeniyle beyin fonksiyonlarını etkilediği ve nöroprotektif etki gösterdiği belirtilmektedir (40).

\section{SONUÇ VE ÖNERİLER}

Kimyasal yapılarına bağlı olarak çeşitli biyolojik aktiviteler gösteren ksantofillerin, birçok hastalığın oluşumuna karşı koruyucu, bazı hastalıkların da tedavisinde destekleyici olarak yer alabildiği görülmektedir. Diyet ksantofillerinin sahip oldukları biyolojik aktiviteler ile göz, kalp-damar, kemik, beyin sağlığı ile diyabet, obezite ve kanserler gibi 
kronik hastalıkların oluşumu ve seyrinde yararlı etkiler oluşturabildiği gösterilmiştir. Ksantofiller ile ilgili çalışmalar, bu bileşiklerin muhtelif etkileri bazen tek bir ksantofil üzerinden, çoğunlukla da ksantofil kombinasyonları ve hatta ksantofil ve diğer antioksidanların birlikte kullanımı ile sağladığını göstermektedir. Ksantofiller için özel bir diyetle alım önerisi yoktur. Genel olarak diyetle veya besin desteği olarak alınması güvenli olarak kabul edilmektedir. Toksik olduklarını gösteren kanıt düzeyinde bir bilgi bulunmamaktadır. Marul, tere, roka, biber, mandalina, portakal, kivi gibi birçok taze meyve ve sebzede yüksek miktarlarda bulunan ksantofilleri yeterlive dengeli bir beslenme şekli ile karşılayabilmek mümkündür. Bu nedenle sağlıklı bir yaşam için günlük beslenmede meyve ve sebze tüketiminin arttırılması ve tüketilen meyve ve sebzelerin renklerine göre çeşitlilik göstermesi önerilmektedir. Günümüzde batı tarzı beslenmenin yaygınlığı düşünüldüğünde, sebze ve meyve tüketimini arttırmanın önemi ortaya çıkmaktadır.

Çıkar çatışması - Conflict of interest: Yazarlar çıkar çatışması olmadığını beyan ederler. - The authors declare that they have no conflict of interest.

\section{KAYNAKLAR}

1. Thomas SE, Johnson EJ. Xanthophylls. Adv Nutr.2018;9:160-2

2. Desmarchelier C, Borel P. Overview of carotenoid bioavailability determinants: from dietary factors to host genetic variations. Trends Food Sci Technol.2017;69:270-80

3. Aghajanpour M, Nazer MR, Obeidavi Z, Akbari M, Ezati P, Kor NM. Functional foods and their role in cancer prevention and health promotion: a comprehensive review. Am J Cancer Res.2017;7(4):740-69.

4. Kotake-Nara E, Nagao A. Absorbtion and metabolism of xanthophylls. Mar Drugs.2011;9:1024-37.

5. GRAS Notice 000588: Zeaxanthin from capsicum. June 25, 2015. Available at: http://www.accessdata.fda. gov_2018 Accessed October 21,2018

6. Tanaka T, Shnimizu M, Moriwaki H. Cancer chemoprevention by carotenoids. Molecules.2012;17:3202-42.

7. European Food Safety Authority (EFSA). Scientific
Opinion on the re-evaluation of canthaxanthin (E $161 \mathrm{~g}$ ) as a food additive. EFSA J.2010; 8(10):1-42.

8. Kishimoto Y, Yoshido H, Kondo K. Potential antiatherosclerotic properties of astaxanthin. Mar Drugs.2016;14(35):1-13.

9. Stewart JS, Lignell A, Pettersson A, Elfving E, Soni MG. Safety assessment of astaxanthin-rich microalgae biomass: Acute and subchronic toxicity studies in rats. Food Chem Toxicol.2008;46(9):3030-6

10. European Food Safety Authority (EFSA). Opinion of the scientific panel on additives and products or substances used in animal feed on the request from the commission on the safety of use of colouring agents in animal nutrition. EFSA J. 2006;386:1-40.

11. Maeda H, Hosokawa M, Sashima T, Funayama K, Miyashita K. Effect of medium-chain triacylglycerols on anti-obesity effect of fucoxanthin. J Oleo Sci.2007;56(12):615-21.

12. Widomska J, Subczynski WK. Why has nature chosen lutein and zeaxanthin to protect the retina? J Clin Exp Ophthalmol. 2014;5:326.

13. Skibsted LH. Anthocyanidins regenerating xanthophylls: a quantum mechanical approach to eye health. Curr Opin Food Sci. 2018;20:24-9.

14. Liu R, Wang T, Zhang B, Qin L, Wu C, Li Q, et al. Lutein and zeaxanthin supplementation and association with visual function in age-related macular degeneration. Invest Ophthalmol Vis Sci.2014;56:252-8.

15. Otsuka T, Shimazawa M, Nakanishi T, Ohno Y, Inoue Y, Tsuruma K, et al. The protective effects of a dietary caretenoid, astaxanthin, against light-induced retinal damage. J Pharmacol Sci.2013;123:209-18.

16. Yeh PT, Huang HW, Yang CM, Yang WS, Yang $\mathrm{CH}$. Astaxanthin inhibits expression of retinal oxidative stress andinflammatory mediators in streptozotocininduced diabetic rats. PLoS One.2016;11(1):1-20.

17. Niranjana R, Gayathri R, Mol SN, Sugawana T, Hirata T, Miyashita K, et al. Carotenoids modulate the hallmarks of cancer cells. J Funct Foods.2015;18:968-85.

18. Yasui Y, Hosokawa M, Mikami N, Miyashita K, Tanaka T. Dietary astaxanthin inhibits colitis and colitis-associated colon carcinogenesis in mice via modulation of the inflammatory cytokines. Chem Biol Interact.2011;193:79-87.

19. Tanaka T, Morishita Y, Suzui M, Kojima T, Okumura A, Mori H. Chemoprevention of mouse urinary bladder carcinogenesis by the naturally occurring carotenoid astaxanthin. Carcinog.1994;15:15-9.

20. Das SK, Hashimoto T, Kanazawa K. Growth inhibition of human hepatic carcinoma HepG2 cells by fucoxanthin is associated with down-regulation of cyclin D. Biochim Biophys Acta.2008;1780:743-9. 
21. Zhang Z, Zhang P, Hamada M, Takahashi S, Xing G, Liu $J$, et al. Potential chemoprevention effect of dietary fucoxanthin on urinary bladder cancer EJ-1 cell line. Oncol Rep.2008;20:1099-103.

22. Toniolo P, Van Kappel AL, Akhmedkhanov A, Ferrari P, Kato I, Shore RE, et al. Serum carotenoids and breast cancer. Am J Epidemiol.2001;153(12):1142-7.

23. Michaud DS, Feskanich D, Rimm EB, Colditz GA, Speizer FE, Willett WC, et al. Intake of specific carotenoids and risk of lung cancer in 2 prospective US cohorts. Am J Clin Nutr.2000;72:990-7.

24. Bakker MF, Peeters PH, Klaasen VM, Bueno-de-Mesquita $\mathrm{HB}$, Jansen EH, Ros MM, et al. Plasma carotenoids, vitamin $\mathrm{C}$, tocopherols, and retinol and the risk of breast cancer in the European Prospective Investigation into Cancer and Nutrition cohort. Am J Clin Nutr.2016;103(2):454-64.

25. Leermakers ET, Darweesh SK, Baena CP, Moreira EM, Van Lent DM, Tielemans MJ, et al. The effects of lutein on cardiometabolic health across the life course: a systematic review and meta-analysis. Am J Clin Nutr.2016;103(2):248-94.

26. Chung RW, Leanderson P, Lundberg AK, Jonasson L. Lutein exerts anti-inflammatory effects in patients with coronary artery disease. Atherosclerosis.2017;262:87-93.

27. Xu XR, Zou ZY, Xiao X, Huang YM, Wang X, Lin XM. Effect of lutein supplement on serum inflammatory cytokines ApoE and lipid profiles in early atherosclerosis population. J Atheroscler Thromb.2013;20:170-7.

28. Uchiyama K, Naito Y, Hasegawa G, Nakamura N, Takahashi J, Yoshikawa T. Astaxanthin protects $\beta$-cells against glucosetoxicity in diabetic $\mathrm{db} / \mathrm{db}$ mice. Redox Rep.2002;7:290-3.

29. Ni Y, Nagashimada M, Zhan L, Nagata N, Kobori M, Sugiura M, et al. Prevention and reversal of lipotoxicityinduced hepatic insulin resistance and steatohepatitis in mice by an antioxidant carotenoid, $\beta$-cryptoxanthin. Endocrinology. 2015;156:987-99.

30. Jung HA, Islam N, Lee CM, Jeong HO, Chung HY, Woo HC, et al. Promising antidiabetic potential of fucoxanthin isolated fromthe edible brown algae Eisenia bicyclis and Undaria pinnatifida. Fish Sci.2012;78:1321-9.

31. Tsuchida T, Mukai K, Mizuni Y, Masuko K, Minagawa K. The comparative study of $\beta$-cryptoxanthin derived from Satsuma mandarin for fat of human body. Jpn Parmacol Ther.2008;36:247-53.

32. Burri BJ, La Frano MR, Zhu C. Absorption, metabolism, and functions of $\beta$ - cryproxanthin. Nutr Rev 2016;74(2):69-82.

33. Yamaguchi M, Igarashi A, Morita S, Sumida T, Sugawara K. Relationship between serum $\beta$-cryptoxanthin and circulating bone metabolic markers in healthy individuals with the intake of juice (Citrus unshiu) containing $\beta$-cryptoxanthin. J Health Sci.2005;51(6):73843.

34. Das SK, Ren R, Hashimoto T, Kanazawa K. Fucoxanthin induces apoptosis in osteoclast-like cells differentiated from RAW264.7 cells. J Agric Food Chem.2010;58:6090-5.

35. Grimming B, Kim SH, Nash K, Bickford PC, Shytle RG. Neuroprotective mechanisms of astaxanthin: a potential therapeutic role in preserving cognitive function in age and neurodegeneration. GeroScience.2017;39:19-32.

36. Cho KS, Shin N, Kim S, Lee SB. Recent advances in studies on the therapeutic potential of dietary carotenoids in neurodegenerative diseases. Oxid Med Cell Longev.2018:1-13.

37. Ademowo OS, Dias HKI, Milic I, Devitt A, Moran R, Mulcahy R, et al. Phospholipid oxidation and carotenoid supplementation in Alzheimer's disease patients. Free Radic Biol Med.2017;108:77-85.

38. Takeda A, Nyssen OP, Syed A, Jansen E, Bueno-deMesquita B, Gallo V. Vitamin A and carotenoids and the risk of Parkin $\neg$ son's disease: a systematic review and meta-analysis. Neuroepide $\neg$ miology.2014;42(1):25-38.

39. Renzi LM, Bovier ER, Hammond BR. A role for the macular carotenoids in visual motor response. Nutr Neurosci. 2013;16(6):262-8.

40. Manabe Y, Komatsu T, Seki S, Sugawara T. Dietary astaxanthin can accumulate in the brain of rats. Biosci Biotechnol Biochem.2018;82(8):1433-6. 